\title{
Article
}

\section{Onward: How a Regional Temperance Magazine for Children Survived and Flourished in the Victorian Marketplace}

Mcallister, Annemarie

Available at http://clok.uclan.ac.uk/13376/

Mcallister, Annemarie ORCID: 0000-0003-0615-3262 (2015) Onward: How a Regional Temperance Magazine for Children Survived and Flourished in the Victorian Marketplace. Victorian Periodicals Review, 48 (1). pp. 42-66. ISSN 0709-4698

It is advisable to refer to the publisher's version if you intend to cite from the work. http://dx.doi.org/10.1353/vpr.2015.0002

For more information about UCLan's research in this area go to http://www.uclan.ac.uk/researchgroups/ and search for <name of research Group>.

For information about Research generally at UCLan please go to http://www.uclan.ac.uk/research/

All outputs in CLoK are protected by Intellectual Property Rights law, including Copyright law. Copyright, IPR and Moral Rights for the works on this site are retained by the individual authors and/or other copyright owners. Terms and conditions for use of this material are defined in the policies page. 


\section{PROJECT MUSE}

\section{Onward: How a Regional Temperance Magazine for}

Children Survived and Flourished in the Victorian Markatnlace

Annemarie McAllister

VICTORIAN

PERIODICALS

REVIEW

Victorian Periodicals Review, Volume 48, Number 1, Spring 2015, pp.

42-66 (Article)

Published by Johns Hopkins University Press

DOI: 10.1353/vpr.2015.0002

$\Rightarrow$ For additional information about this article

http://muse.jhu.edu/journals/vpr/summary/v048/48.1.mcallister.html 


\title{
Onward: How a Regional Temperance Magazine for Children Survived and Flourished in the Victorian Marketplace
}

\author{
ANNEMARIE MCALLISTER
}

Onward! Lord, we press,

Onward led by Thee;

Children of our land to bless-

Drunkards to set free.

Led by thee, Almighty Lord,

Armed by Thy strong shield and sword,

Cheered by Thine eternal word,

Victors we shall be. ${ }^{\mathrm{I}}$

This stirring appeal comes from Onward (I 865-I910), a children's temperance magazine which combined fervent conviction and propaganda with social commentary as a means of responding to the commercial pressures of the journalistic marketplace. As such, it offers a particularly interesting case study for exploration. This essay will map the field of juvenile temperance magazines and then examine the evolution of Onward as one of the highest circulation titles sponsored by any special-interest group during the Victorian era. Onward's marketing and survival strategies have much to teach the student of nineteenth-century print history.

Temperance periodicals, including those for children, are an underresearched genre within nineteenth-century print culture. ${ }^{2}$ The temperance movement attracted large numbers of followers during the second half of the century, with over six million adults and children belonging to temperance organisations by 1900. ${ }^{3}$ Notable editors and publishers, such as G. W. M. Reynolds (I 8I4-79) and John Cassell (I 8I7-65), began their careers by producing temperance publications. Press directories show the importance of such titles in the market; for example, in the I87I edition of May's London Press Dictionary and Advertiser's Handbook, there are 
fifteen temperance periodicals listed, a number exceeded or equalled only by those classed as religious magazines (by far the largest category) and eight other large categories such as legal or science periodicals.

Despite Brian Harrison's magisterial book, Drink and the Victorians, to which all later scholars in the field are indebted, there has been little published on this huge nineteenth-century movement and even less on its survival into the twentieth century. ${ }^{4}$ From the 1830 os to the I930s and beyond, organised temperance societies sought to persuade men, women, and children to regard the consumption of alcohol as dangerous and to sign a pledge of total abstinence. The profound effect of these societies on the contemporary cultural and intellectual landscape has yet to be fully explored, but as James Nicholls remarks, the "movement struck a chord with large numbers of working people, not least because it suggested that personal salvation and social transformation were in their hands, rather than the hands of priests or politicians." 5 On a personal level, teetotalism liberated workers by allowing them to keep their wages rather than handing them over to publicans and brewers, which benefited their families as well. By challenging drinking as a social norm, the temperance movement led men, women, and even children to engage in social and political argument, thus experiencing a sense of agency which was socially liberating in many cases. ${ }^{6}$

The existence of children's temperance societies may surprise modern readers. These organisations not only addressed the significant problem of child drunkenness but also sought to deter children from becoming drinkers and to convert them into lifelong temperance supporters. ${ }^{7}$ The foremost of the juvenile societies, the Band of Hope (I847-I995), later renamed Hope UK, was not the first such group, but it quickly absorbed other juvenile temperance societies, becoming a brand leader, to use a modern term. ${ }^{8}$ Its growth was in part due to its effective national organisation, which had a flair for publicity. It also offered local, district, regional, and national support and provided a thorough system of training for millions of voluntary workers. ${ }^{9}$ Lilian Lewis Shiman suggests that behind much of the organisation's success was the working-class desire for self-improvement and respectability, which is undoubtedly true, but there were clearly other contributory factors accounting for the extraordinary popularity and vigour of the Band of Hope. ${ }^{\text {Io }}$ The organisation attracted young members by providing regular activities for them in relatively pleasant surroundings; encouraging them to identify with a group; rewarding them with markers and symbols of success, such as medals they could proudly wear; and systematically fostering their abilities and skills. But it must be remembered that the organisation was not merely established to provide childcare: it had a moral purpose at its heart. It was an overtly Christian pressure group whose aim was to proselytise and bring about legal and social change. The 
message given to children was that "there is no form of sorrow, no development of sin, no kind of misery, which might not own its parentage in strong drink and intemperance." II

Brian Harrison suggests that the temperance movement, like similar popular pressure groups, had three main functions: to inspire, inform, and integrate. ${ }^{12}$ The latter function is perhaps the most interesting to the modern reader, recalling Benedict Anderson's concept of an imagined community that unites readers in a shared identity through which they define themselves and reinforces their membership in a wider group. ${ }^{\mathrm{I3}}$ Given the religious and moral imperative at the heart of the temperance movement, it might be assumed that the main purpose of education efforts and their related publications was to provide inspiration and information; however, as writers evidently realised, this sort of didacticism would not necessarily attract young readers. If groups were to survive and expand, they needed to create a sense of belonging which validated shared beliefs but also provided enjoyment. As Harrison remarks, "For the temperance movement, as for other radical movements, the answer lay in distributing periodicals." ${ }^{{ }_{4}}$

In the early days of the movement, temperance publications were not very attractive to the growing number of child readers. Illustration, if provided at all, was usually confined to the front cover or a frontispiece, as is shown in the Youthful Teetotaler, founded in I836, and the Youth's Temperance Magazine, which first appeared in January I842. The rapid increase in the number of temperance societies for adults and children in the 1840 s saw a corresponding increase in temperance publications for children, for example, the Juvenile Temperance Messenger and Monthly Instructor (figure I) and the Sunday School and Youth's Temperance Journal, founded in I 846 and I 848 , respectively. The latter publication anticipated one of the major success stories of nineteenth-century publishing when it opportunistically added "and Band of Hope Journal" to its title in I 850 . However, it was soon to be eclipsed, both in circulation and visual appeal, by the two Band of Hope magazines which I discuss below.

The Band of Hope's growth was startling from the outset: while only 300 children attended the first Leeds meeting in I 847 , the number of members grew to 4,000 just a few months later. It continued to expand its national membership by the 1850 , growing to over three million members by the end of the century. ${ }^{\text {Is }}$ From the outset, the Band of Hope stressed that children must be presented with lively and engaging material that would make them keen to attend weekly meetings and other events. This message was later reinforced in the Band of Hope Chronicle (I878-1986), a magazine which provided advice and training for thousands of volunteer workers. Children, their parents, and other volunteer organisers for the Band of Hope were also a huge potential market; thus, the organisation's brand was an attractive feature for publishers or advertisers seeking to gain large circulations. 


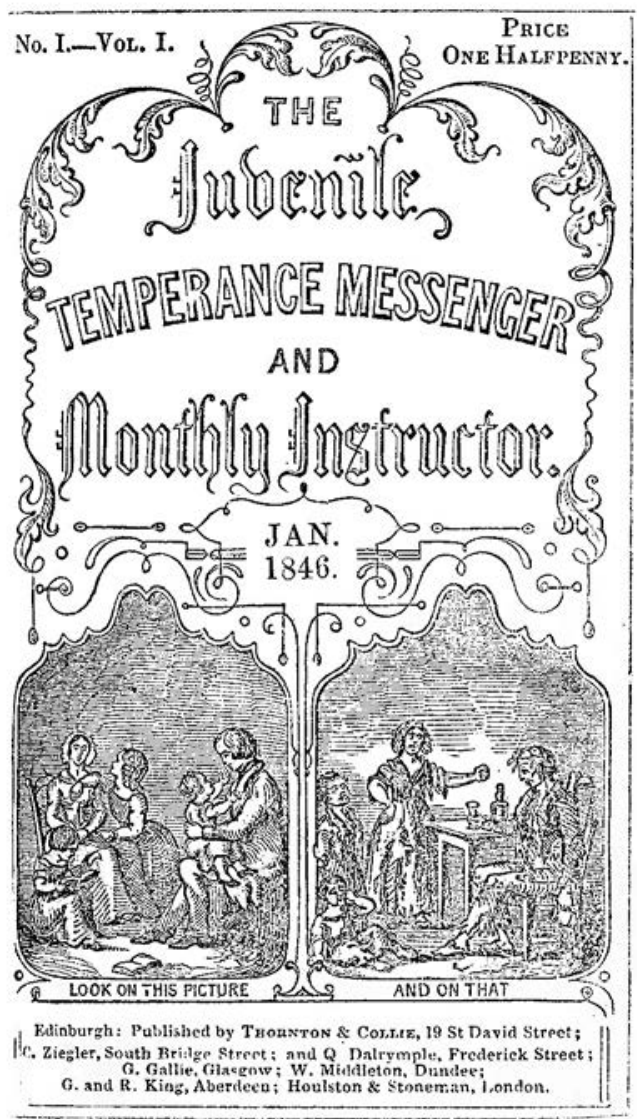

Figure I. Front cover, the Juvenile Temperance Messenger and Monthly Instructor I (January I 846). Courtesy of the Livesey Collection, University of Central Lancashire.

The Band of Hope Review and Sunday Scholar's Friend was founded in $\mathrm{I} 85 \mathrm{I}$ as an engaging alternative to the moralising fare offered by early juvenile temperance periodicals. The magazine was initially printed by William Tweedie in the Strand, a firm that published many temperance titles until I 874, when it moved its printing operations to the shop of Samuel Partridge on Paternoster Row. In addition to founding the magazine, Smithies served as editor for its first thirty-two years. The magazine's aim, he noted, was "to supplement Sunday school instruction, providing temperance advice to the young and serving as a resource for religious and moral teaching in the home." ${ }^{16}$ Smithies placed a high value on illustration, as can be seen spectacularly in his other magazine, the British Work- 
man (I855-I92I). ${ }^{17}$ By the end of the first year, the magazine's name was changed to the Band of Hope Review and Children's Friend, and ten years afterward (in May I86I) it became the Band of Hope Review, a title it retained until ceasing publication in 1937 .

The Band of Hope Review presented a decided contrast to the smaller octavo publications that had previously been offered to children. It was folio sized, with four plentifully illustrated pages, and later it featured highquality, full-page cuts on the cover. The rest of the magazine incorporated vignettes or half-page illustrations along with poems and thought-provoking addresses or short articles amid more devotional or proselytising prose. The Band of Hope Review was in tune with the trend for human interest stories and more easily readable features, as was already seen in cheap sensational papers and would later develop into the New Journalism. It described children in various worthy endeavours, such as saving animals in danger or calculating how long it would take "to supply a Bible to every one of the 7,000,000,000 of our poor benighted heathens, at the rate of $\mathrm{I}, \mathrm{I} 36,695$, as supplied in the year I $849 .{ }^{\prime \prime}{ }^{18} \mathrm{~A}$ key feature of every issue was the "motto," a Biblical or advisory text enclosed within an elaborate border which supported the magazine's firmly religious tone. When quizzes were offered, they were focused on the Bible, and almost every item had an explicit reference to Christian teaching. However, this material was presented in a relatively lively way, with engaging illustrations and up to ten short items on each page. Figure 2, from the first issue, shows a typical trope in Band of Hope iconography: the child David challenging Goliath, who is re-imagined as "Giant Alcohol" in order to emphasise the enormity of the problem. The illustration encourages children to feel that they can defeat this enemy through ingenuity, persistence, and divine help.

Circulation figures indicate what a huge market the children's temperance press rapidly became. In I 860-6I, for example, the three weekly adult temperance newspapers claimed a combined circulation of only 25,000 , and two quarterly reviews achieved a joint figure of 10,000 , but the Band of Hope Review's circulation was over 250,000. ${ }^{19}$ In comparison, Boys of England (I866-99), the general market leader until I879, also claimed 250,000 copies sold but only midway through its run in the I 870 os. ${ }^{20}$ The Band of Hope Review had clearly become something of a giant itself, but another David was soon to enter the battle.

The largest regional division of the national Band of Hope was the Lancashire and Cheshire Band of Hope Union, founded in I 863. The first such union to be incorporated, it soon established itself as the fastest growing and most dynamic regional group. Exact membership figures during the early years are hard to come by, but later records indicate that by I 865 it claimed over 20,000 members and by $1870,70,000$. In the next fifteen years, it doubled this number, growing steadily to just under half a mil- 


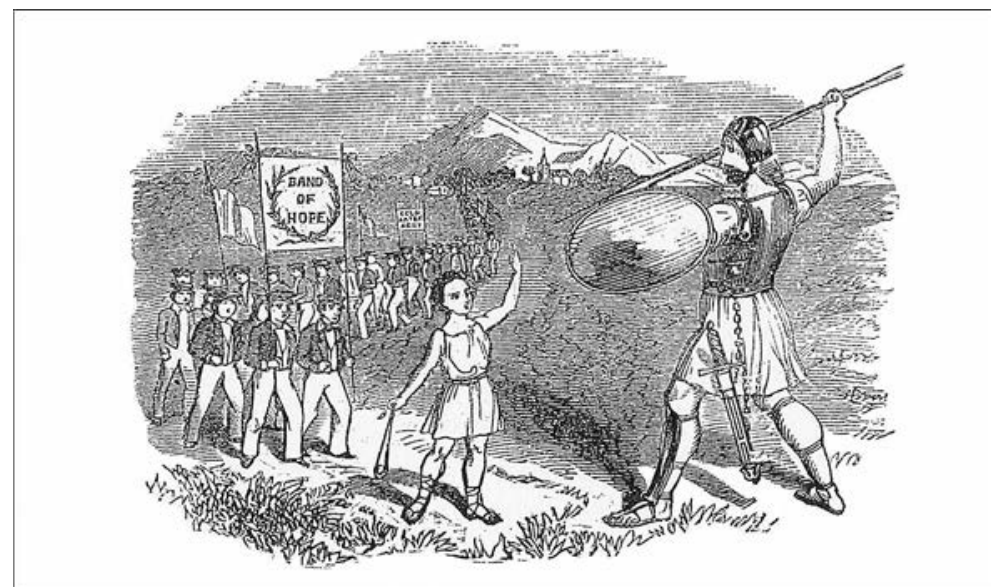

Figure 2. "The Great Giant," Band of Hope Review and Children's Friend I (January I 8 5 I): 3. Courtesy of the Livesey Collection, University of Central Lancashire.

lion members in 1930. Entrepreneurship appears to have been one of the organisation's particular characteristics: its reports frequently reference membership drives and money-raising activities such as bazaars. Indeed, during a period when the national organisation was struggling financially (1902-5), the Lancashire and Cheshire Band of Hope Union raised the massive sum of $£_{\mathrm{I} 5,000}$ for a new building in Manchester. ${ }^{2 \mathrm{I}}$ Thus, it is hardly surprising that two years after it was formed, the group decided to issue its own children's periodical, Onward: The Organ of the Lancashire and Cheshire Band of Hope Union (1865-1910).

While the Band of Hope Review boasted an imposing folio size, highquality illustrations, and a circulation of 250,000 , Onward ventured into the field with a sixteen-page octavo format with an illustrated cover but no other illustrations. Its ambitious aim was to "maintain and extend the influence [of the Lancashire and Cheshire Band of Hope Union] beyond its present local phase." ${ }_{22}$ It was presumably for this reason that it was published not only in Manchester but also in London by the same firm that produced the Band of Hope Review. The first issue had an unvaried letterpress format and long articles with titles such as "Temperance and the Franchise," which suggests that it was largely directed at an adult readership. Taken as a whole, it is an unprepossessing production, very much on the pattern of the Juvenile Temperance Messenger and Monthly Instructor. This would seem to have ensured its failure, but its martial, snappy title was indicative of its potential. Rather than mimicking the Band of Hope Review by changing its cover image weekly, Onward repeated the same illustration as a trademark (figure 3). It is attractive but also fulfils a teach- 


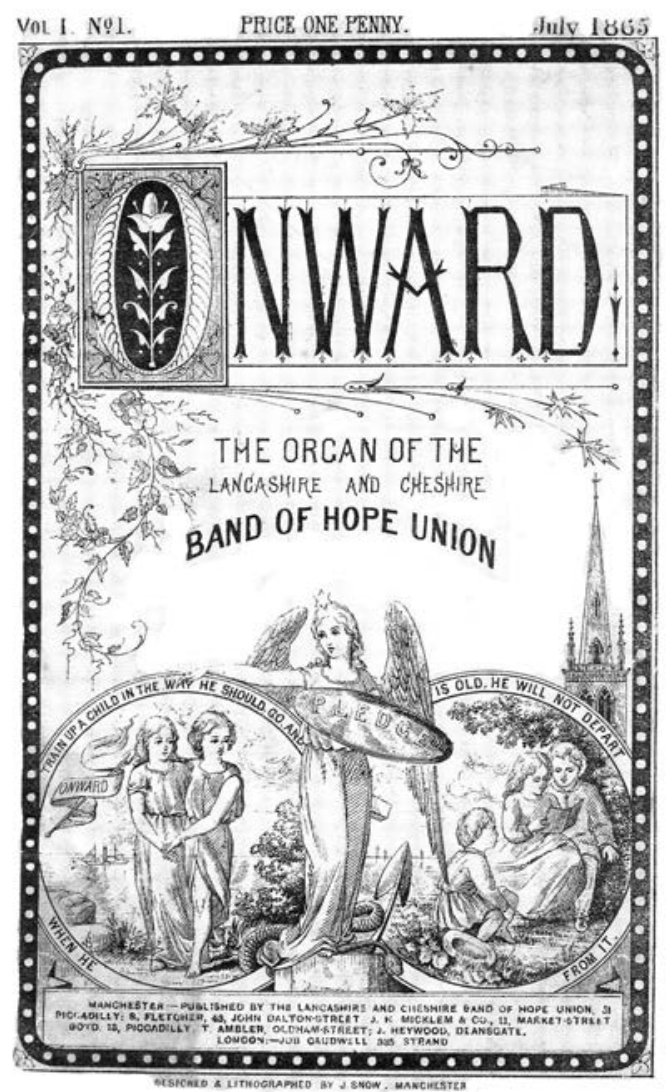

Figure 3. Front cover, Onward I (July I 865). Courtesy of the Livesey Collection, University of Central Lancashire.

ing function by using temperance iconography. The image shows Temperance trampling a serpent with the pledge as her shield, while pointing to the biblical motto which was frequently used in the Band of Hope: "Train up a child in the way he should go and when he is old, he will not depart from it" (Proverbs 22:6). The vignettes depict children in idealized rural settings rather than urban locales, and the church spire reminds readers of the organisation's religious links. Rather than following in the footsteps of the Band of Hope Review by providing richly detailed illustrations such as "Christ Blessing the Little Children" (January I 865) or "Daniel in the Lions' Den” (October I 865), Onward used a more symbolic emblem that encouraged children to decode and explore the layers of reference, setting a pattern for their active engagement as readers. 
Reader activity and choice are keynotes of periodical consumption. Margaret Beetham defines the periodical as a mixed genre in which elements are presented and reproduced within a particular template yet are varied from issue to issue, thus encouraging a selective reading practice. ${ }^{23}$ As readers navigate their way through the periodical, taking a customary route or forging new paths, they can choose to focus on or omit any given section. As Deborah Wynne remarks of family magazines, "The culture of thrift and recycling which underpinned Victorian middle- and lower-class life must have played a part ... [and] newspapers and magazines were perused more intently by people lacking the distractions of other media forms." ${ }_{24}$ Each issue of a periodical may be seen as offering a menu presenting a set of reading options within a familiar framework from which the reader can select, combine, and consume.

It was the menu of Onward that made it so different than the Band of Hope Review. While the periodical's contents were initially rather uninspiring, the editor showed himself well able to adapt to the needs of his audience, soon presenting jokes and songs as well as a more informal overall tone that emphasised personal interaction with readers. ${ }^{25}$ Religion remained evident in references to churchgoing, divine intervention, and the holiness of temperance, but these elements were encountered in passing as part of stories or articles, rather than as the primary focus of the magazine, as was usually the case in the Band of Hope Review. When the word "religion" did appear with "temperance" in an article title, Onward acknowledged that the concepts were distinct and that it was possible to have the virtue of one without the other. For example, an I 867 article "Temperance and Religion" begins by asserting that "Temperance and Religion are two distinct things." ${ }^{26}$ Even though the article concludes by "thank[ing] God that the leaders of our glorious and triumphing temperance cause are followers of Christ," it does not include the biblical mottos highlighted in a typical issue of the Band of Hope Review. ${ }^{27}$

At the end of Onward's first year, the editor wrote a retrospective preface for the collected volume indicating his awareness of the magazine's success in the competitive market for children's periodicals:

Ours is a pleasing retrospect. With diffidence a year ago we ventured to send forth a new claimant for public support and sympathy, and we naturally felt anxious for the result. Our design embraced no envious jealousies. We had no desire to oppose or injure those noble workers in the field of pure literature, the "British Workman," "Band of Hope Review," "Adviser," "Children's Friend," "Children's Prize," or the little "Dewdrop," with a host of others. To all such we say, God speed your efforts, may you increase a thousandfold. But we did feel that there was still a distinctive want, a niche in the vestibule of Temperance literature, which the rapid development of the Band of Hope 
movement had created, and which we designed to fill with our little magazine. With deep gratitude to God, and heartfelt thanks to those who have so generously assisted us, we have to record a success in the first volume more than we had anticipated. ${ }^{28}$

But if Onward sought to inspire, inform, and engage its young readers, it also needed to secure the loyalty of that audience in order to survive financially. Like publications produced by other philanthropic or religious groups, temperance periodicals often received subsidies, but they usually had to supplement these funds with proceeds from subscriptions or bookstall sales. ${ }^{29}$ By the time Onward first appeared in I 86I, the marketplace was crowded with competing publications. This glut of mass-market publishing for children resulted from the combined forces of the Sunday school movement, the Society for the Propagation of Christian Knowledge, and the Religious Tract Society, all of which sought to encourage and exploit the growth of literacy by engaging young readers. The editor of Onward regularly discussed the importance of increasing circulation. In August I 866, he noted that circulation had reached 7,000, and in the same issue, an article encouraged further subscriptions:

In many of our more prosperous Bands of Hope there is also the system, where members paying a penny or twopence each month receive in return a temperance publication monthly, such as each may choose, and periodically a free ticket of admission to tea parties or other entertainments got up for their special benefit. This is found on the whole to be a happy arrangement. The amount of temperance literature which by this plan is thrust into circulation through the children, read by themselves, and introduced into their homes to be read by the various members of their families respectively, is computed to be, at a very low estimate, no less than I20,000 numbers annually of such serials as the "Adviser," "Band of Hope Review," "British Workman," and the "Onward." One society alone disposed of 2,500 numbers in this manner, and sold I, IOo more, a total of $3,600 .^{3 \circ}$

Another strategy was to add particularly relevant content to local editions, known as "localizing." A local Band of Hope group agreed to purchase a regular number of copies which were supplied bound with extra local sections and covers. Sadly, few such editions have survived, but there is one remaining example from Preston with an extra four-page supplement bound onto the outside of the "standard" copy for that month which includes references to local events and news. ${ }^{3 \mathrm{I}}$

From an early stage, Onward was entrepreneurial in its approach to building its readership: in its third year, for example, it made reference to subscribers in Guernsey and Swansea and proudly announced that the 
"committee of the Glamorganshire Band of Hope Union is endeavouring to put 'Onward' in the hands of every young man and woman in the union, believing it to be the best penny monthly published; they hope to be able ere long to order at least 500 monthly." ${ }^{2}$ Although it aimed to reach a national audience, Onward still remained grounded in its regional identity, a status which was frequently celebrated and even mythologised. The editor bubbles over with tales of industry and success, noting that "at Manchester we are always busy somewhere." ${ }_{33} \mathrm{He}$ goes on to recount that when the Band of Hope was commenced at Newton Heath Wesleyan Sunday School two and a half years before, "there were three abstaining teachers: now there are fourteen!" 34 The modern reader will notice the self-referential nature of much of the editorial commentary. In its third year, Onward changed the title of its monthly editorial column to "Editor's Chat," thus referring explicitly to the role of the editor in the production of the magazine and creating a human figure to engage with readers. It explains that the change will be "expressive of greater variety, and ... a homely one, and will better afford the freedom, so as to make our intelligence both pleasant and instructive." ${ }_{55}$ Magazines such as Chatterbox (I 866-I953), Little Folks (I87I-I933), and the Boys' Own Paper (I879-1969) also adopted an accessible tone and presentation. Onward's changes along these lines served both to integrate its readers into the Band of Hope community and to respond to the innovations made by other juvenile titles in the market. ${ }^{36}$

It is interesting to compare Onward with the Band of Hope Review during the $\mathrm{I} 860 \mathrm{os}$. The Review contains no regular editorial address (until over thirty years later) and minimal branding or self-promotion. In an I 865 advertisement, the editor notes that the Band of Hope Almanac "may now be had through any bookseller. The chief engraving is 'Mike Donovan's Looking-glass,' which we think will be prized by our friends." ${ }^{77}$ However, such self-advertisement was rare in the Band of Hope Review. As this advertisement emphasises, illustrations were the glory of the Review and its associated almanacs. The whole attractive page on which this advert appears is shown in figure 4 .

For its first eight years, Onward was unable to match the quantity or quality of its rival's illustrations, but it nevertheless adopted some ingenious strategies for attracting young readers which surpassed those of its direct competitor. It not only directly addressed children as readers but also provided them with "interesting tales, anecdotes, and facts, with original and select songs, music, and recitations." ${ }^{8}$ The adult audience of the first issue of Onward was indicated in its solemn editorial address, but a younger readership was suggested in the second issue by the inclusion of a song. By the third issue, there were two songs and two "Pages for the Young Ones." ${ }_{39}$ From issue four, October I 865, Onward began addressing children in an even more personal way, with "Uncle Ephraim" narrating 


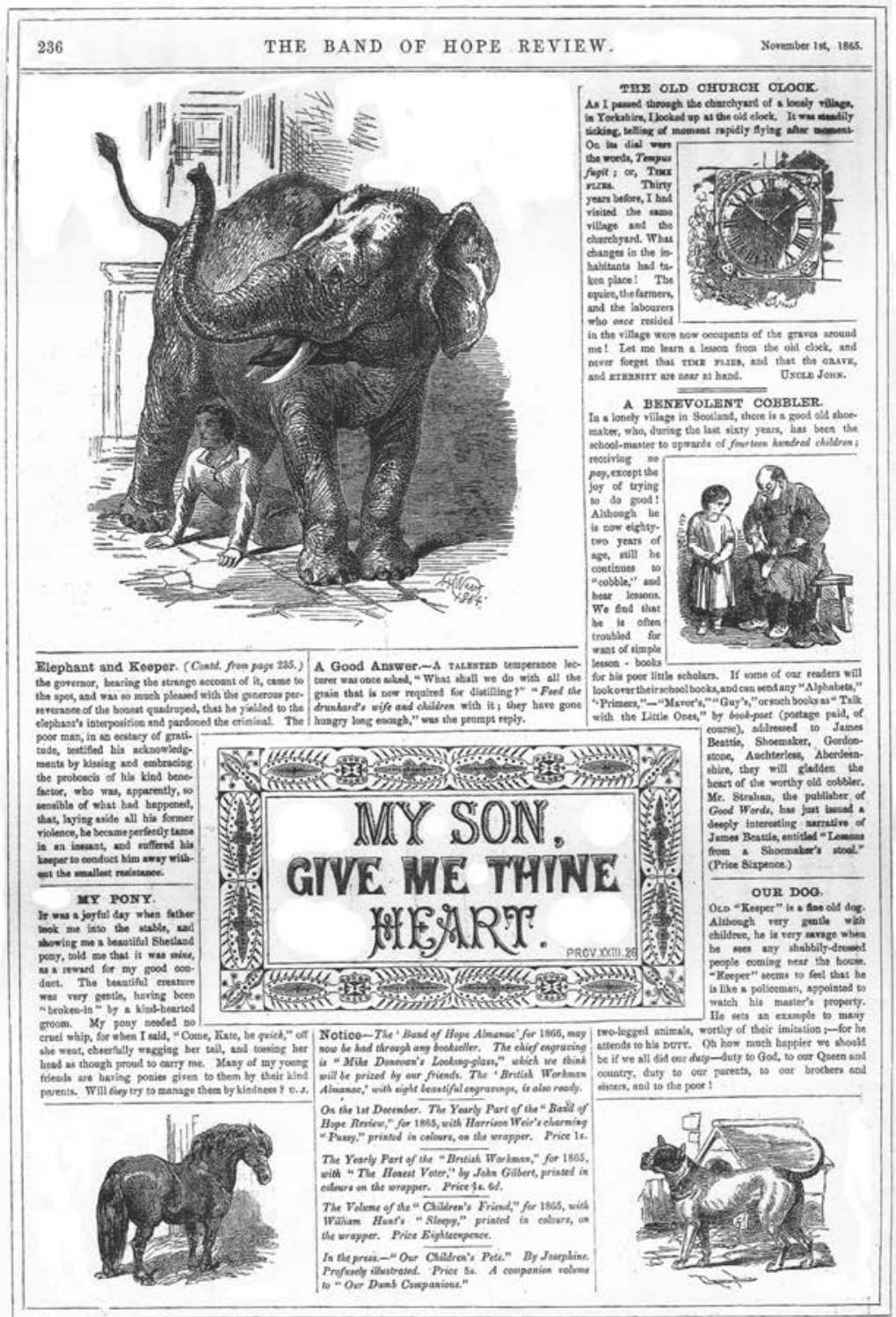

Figure 4. Page layout, Band of Hope Review 59 (November I 865): 236. Courtesy of the Livesey Collection, University of Central Lancashire. 
the four "Pages for the Young," writing from the unlikely sounding "Crystal Cottage, Manchester." ${ }_{40}^{\circ}$ In the next issue, the children's pages were written by "Cousin Edward from London," and the adult-focused "Intelligence," which encapsulated Band of Hope news nationally and locally, was reduced to two pages. Eventually this news column disappeared entirely. From this fifth issue, Onward featured short fiction, and from its eighth issue it incorporated a serial story designed to maintain young readers' interest. The first story was by an unknown writer named "Adeline," but later serials were contributed by prominent temperance authors such as Clara Lucas Balfour.

Beginning with the second issue, poems were featured, and the third issue offered "An Original Lancashire Recitation" titled "Aw Tell Thee Wot, Ned," which reflected the magazine's northern origins. In the ninth issue, another recitation was offered, "Eawr Village" by Uncle Abraham, and in later years dialect poems by notable poets such as Samuel Laycock ( $1826-93$ ) appeared at regular intervals. Despite Onward's growing national reach, its dialect poems were always in Lancashire vernacular, which may well have mystified some readers. The publication of these poems nevertheless affirmed Onward's distinctive northern character. Unlike the Band of Hope Review, Onward not only included poetry but also recitations and songs that encouraged readers to interact with the magazine and to engage with others.

From the fourth issue, Onward printed songs with sheet music, and for the next forty-five years, it continued to print at least one song per issue, once again distinguishing itself from the Band of Hope Review, which did not print music until I 87 I and then only rarely..$^{4 \mathrm{I}}$ Songs played an important role in the temperance movement and consequently were more likely to appear in temperance magazines than in other children's periodicals. From its September I 866 issue, Onward also consistently published songs with tonic sol-fa notation, a system originally devised as an empowering and accessible method for working-class learners to read music. This method grew symbiotically with the temperance movement, sharing its emancipatory mission to offer alternative pleasures to drinking and also formed part of the rational recreation movement. ${ }^{42}$ Space does not allow exploration of the tonic sol-fa movement here, but it is important to note that the Band of Hope widely promoted the method, particularly in the northern unions, where the organisation's membership was high, as well as in working-class districts such as Newton Heath or Ancoats. It is perhaps less than surprising that the Band of Hope Treasury (I 869-90), the only other children's temperance magazine yet discovered which also printed songs every month with tonic sol-fa notation, was also edited in Manchester by Onward contributor William Hoyle. It was a smaller and less ambitious periodical than Onward in terms of content, national reach, and circulation, but Hoyle was a noted composer and arranger. ${ }^{43}$ 
Like the Band of Hope Review, Onward held competitions, but it did not usually focus these contests on Biblical questions. In May I 868, a prize was offered for an essay addressing the question "Why Am I an Abstainer?" This strategy for engaging readers developed into the regular publication of readers' work. Figure 5 shows an example from ten years later, where an essay by a fourteen-year-old reader, "How I Spent a Day at the Seaside," is used as the focal point of an impressive double-page spread with an accompanying illustration and poem. The young author, Bertha Davies, is placed at the centre of the text. In contrast, the Band of Hope Review did not incorporate children's writing until twenty years later. When it positioned children as agents, it discussed them in the third person, for example, as "our readers," who might "affect a positive influence on drunkards." ${ }^{44}$ From the early years, moreover, the names and locations of prize winners of Onward's competitions were noted in the magazine. Letters from "Cousin Edward, of London" likewise encouraged readers to see themselves as a national community and to be proud of the Band of Hope-and their magazine. As Cousin Edward exclaimed, "Look for one moment at the improved and creditable manner in which our editor has brought out 'Onward.' Does not this look cheering?” 45

Onward was of course primarily focused on temperance, but it nevertheless provided a varied menu within this field by addressing readers informally, engaging in self-mythologisation, and publishing a variety of content designed to appeal to the differing ages, genders, and interests of its readers, with topics ranging from history and riddles to football and flowers. This wide-ranging approach encouraged what Martin Barker, in his analysis of Jackie magazine, calls an "unwritten contract with the readers" premised on providing a collage of different approaches and content. ${ }^{46}$ Drawing on readers' experiences and naming contributors further promoted the magazine's community feeling, which was then reinforced by the regular "Editor's Chat" feature. By reading serials, competitions, gossip, and other features of Onward's regular menu, readers could define themselves in relation to the local, regional, or national Band of Hope union. Margaret Beetham and Louis James have explored the varied possibilities inherent in the consumption of periodicals, particularly the ways they provide readers with the pleasure of participating in a community with shared values. ${ }^{47}$ Martin Conboy's comments on newspapers also apply to Onward's mission of engaging readers as a means of attaining financial viability. He notes that the "dialogue between readers and popular newspapers, whether literal, as in the letters pages, or part of the textualization of the readership in the layout, language and advertising of the newspaper, became a critical and a dynamic component in the legitimation of its popular appeal and thereby its commercial success." ${ }^{48}$ 


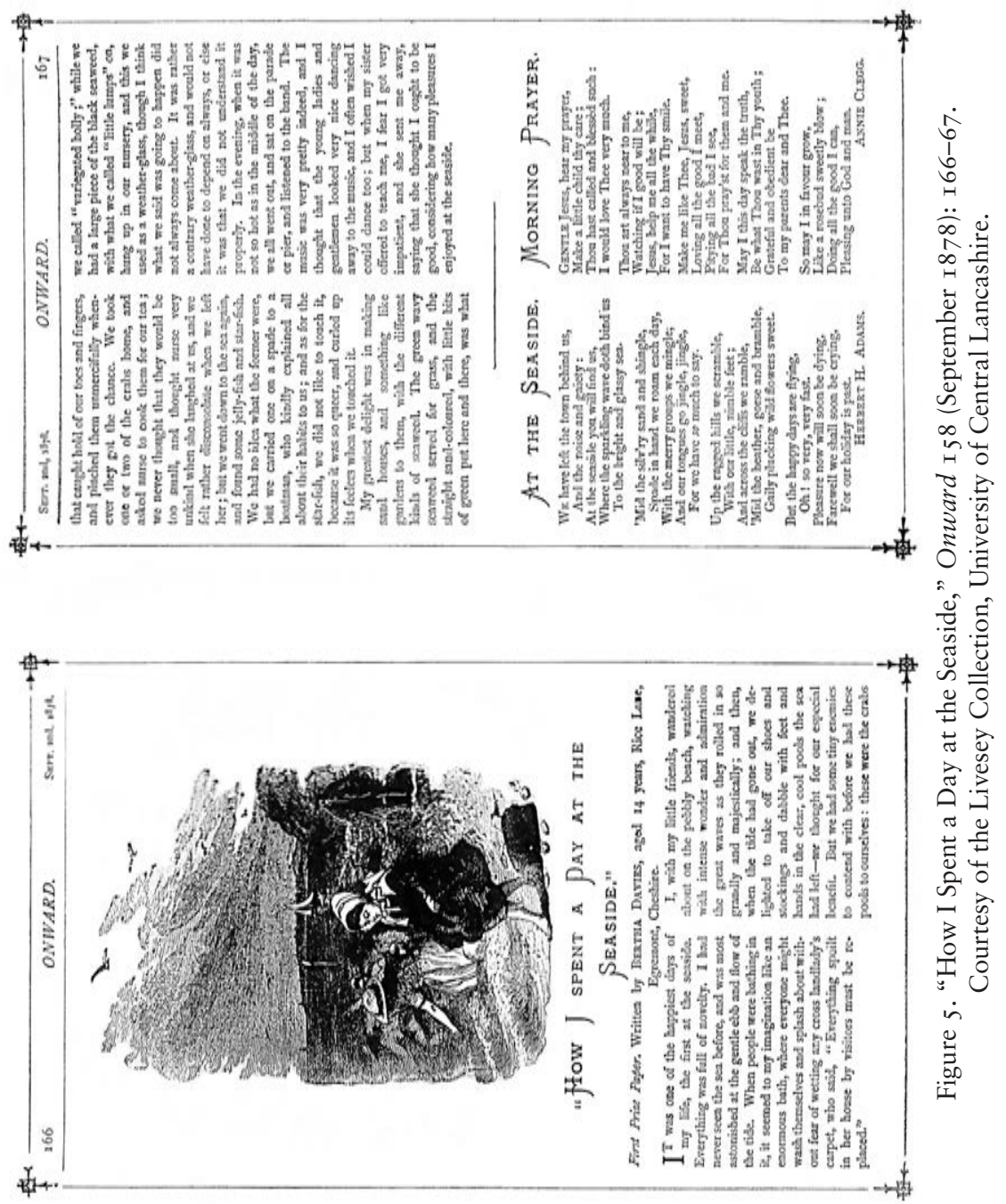


From the mid-I870s, Onward advertised itself as "A Magazine for Family Reading," and advertisements found in the few unbound copies that still exist feature the kinds of household items usually advertised in temperance publications: cocoa, coffee, fruit drinks, and non-alcoholic medical remedies. However, even though child readers were unlikely to be consumers, they remained the main focus of the magazine. From the end of its second year, Onward no longer included a significant amount of material directed overtly to adults. Even when it occasionally published practical articles for adult temperance workers, advice was always at least in part devoted to empowering children. For example, one such article, "Band of Hope Management," notes that "young speakers sometimes fail through want of confidence. . . . Time and perseverance will overcome great difficulties." 49 Throughout Onward, children are addressed as empowered agents in the war against drinking. This distinguishes it from the Band of Hope Review which from I 870 to I 899 was dominated by religion and scripture as well as features on the welfare of animals and the exercise of virtues such as obedience and industriousness. In contrast, Onward was more diversified in its content. "Pebbles and Pearls," for example, was a regular feature published at the end of each month's issue which featured temperance-related items but also secular quotations and aphorisms beside Punch-style wordplay and jokes. A typical example reads, "A man who was formerly a night-watchman refers to it as his "late occupation." "50

Onward was thus informal, lively, practical, and much less overtly religious than the Band of Hope Review. During its first nine years, Onward's more light-hearted approach was indicated through its typography, particularly its use of exclamation marks and elaborate typefaces. Deprived of the resources to include illustration along the same lines as the Review, Onward began to play creatively (perhaps even rather wildly) with the resources available in the printer's shop (figure 6). This page, from Onward's third year of operation, shows great ingenuity in attempting to make the magazine visually arresting, with engaging borders, initial letters, and typography. The typefaces draw attention to themselves both to advertise content and to create a relaxed, almost comic effect, just as they did in Punch during the same period. By I872, its seventh year, Onward finally began to use illustrations, at first with single pages inside the front cover and then with illustrated capitals. After transferring to Partridge's printing firm in 1874 , Onward immediately began to integrate small vignettes and elaborate capitals in the text of the magazine. By January I 875 , not only were larger vignettes used to illustrate stories but blocks were incorporated at the borders of pages to create a more creative design, one which significantly did not employ the "grid" system used by many journals, including the Band of Hope Review. A page from I 880 provides a beautiful example of how creative design could be used to attract readers (figure 7). It sug- 


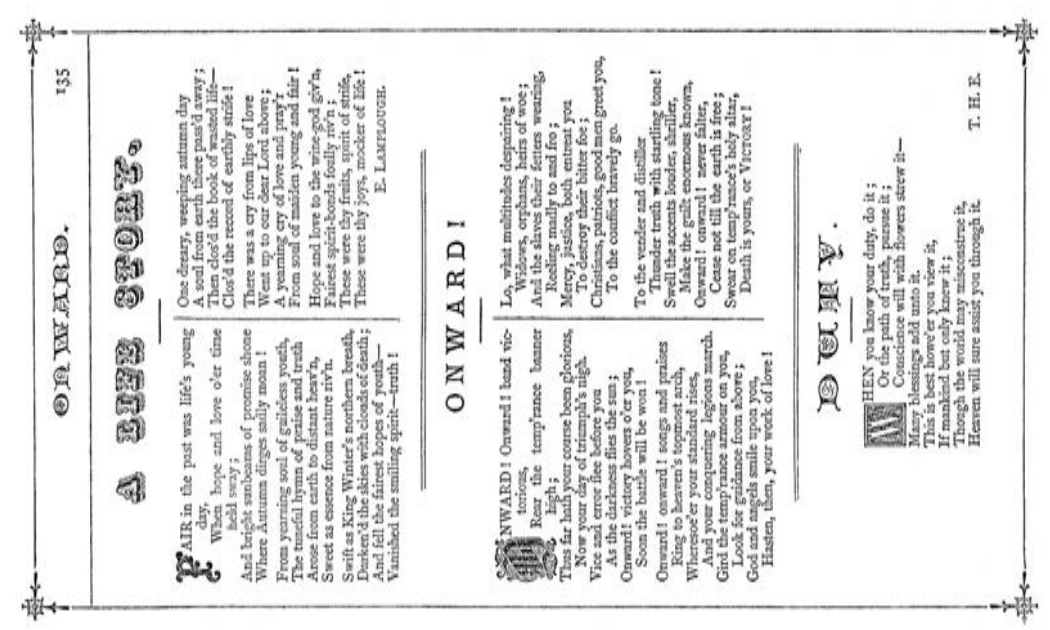

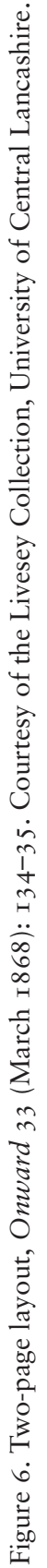




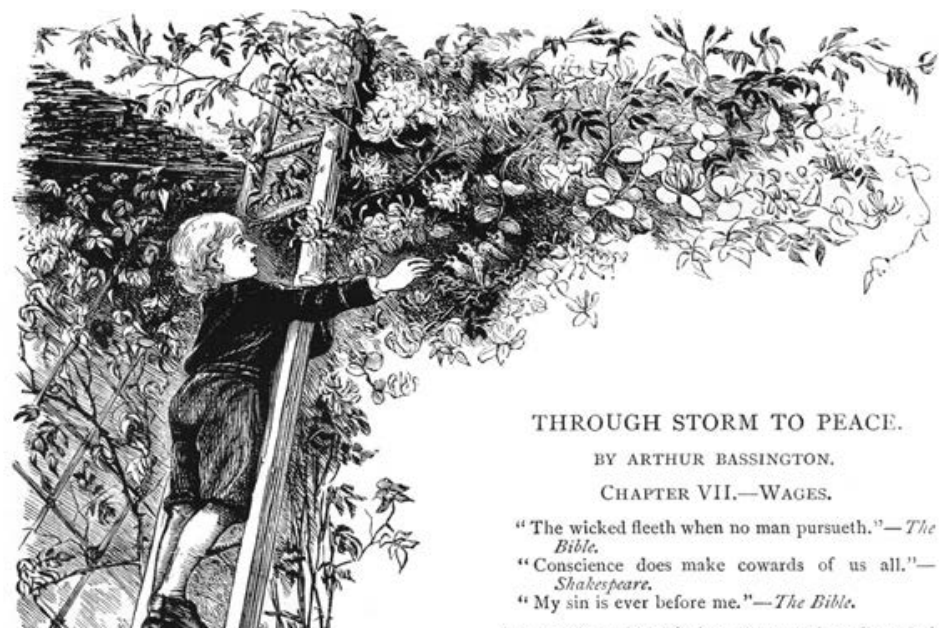

$\mathrm{W}^{\text {HEN John Linden staggered and reeled }}$ thrown Jenny, bewildered by the news he had heard, terrified by the new sense of guilt which ran in his drunken brain as the words echoed and echoed again and again, "You did it!" he knew not what to do or which way to turn.

At first he went forward, too drunken and besotted to know why or where : he dreaded to go home. Scarcely conscious of the direction he took, he wandered with unsteady footsteps from one side of the road to the other, until he fell into the ditch, where he remained for some little time unable to get up. He slept, but not for long; awoke to find it all dark, and himself wet and cold. The shock he had received had helped to sober him. He feared to go home : his wife must know since Jenny knew, and he could not meet her gaze; besides, before long the police would be sure to seek him-now, while he had time and opportunity, he had better escape. The night was dark and rough with wind and rain. After some hasty reflection he made up his mind to walk, at least till daylight, on the way to London, and to gain the main turnpike-road which led to the great city he had only to go down a short country lane and avoid all the main part of the village, and be in the opposite direction to his cottage and the market town. The very thought of his home sc sickand faint. He journeyed on through sleeping

Figure 7. "Through Storm to Peace," Onward I70 (July I 880): 97. Courtesy of the Livesey Collection, University of Central Lancashire.

gests the movement of a child reaching for fruit by directing the reader's eye to move up and across the page. ${ }^{\text {I }}$

In addition to improving its design, Onward gradually began to expand in size. It never reached the dimensions of the folio Band of Hope Review, but there was a discernible sense of expansion. From its inception in I 865 until I 879 , its dimensions were $8^{1 / 4} \times 5^{1 / 4}$ or $5^{1 / 8}$ inches, but from I 880 to I 889 , it grew to $83 / 4 \times 63 / 4$ inches, in I 890 it was enlarged to $9^{3} / 5 \times 7$ inches, and finally from I $89 \mathrm{I}$ to I9IO, it was resized yet again to $9^{3 / 5} \times 7^{1 / 8}$ inches. 
In making these changes, Onward was responding to developments in the wider field of children's magazines rather than imitating the formula of its closest competitor, the Band of Hope Review. While the Review was "lavishly illustrated by some of the best artists of the period," Onward incorporated an even greater number of sophisticated illustrations as well as content from well-known temperance authors, along with songs and recitations..$^{52}$

The I 880 s, I 890 s, and early I 900 s can be seen as Onward's zenith. Following the Band of Hope's development of methods for teaching scientific temperance in schools during the late $\mathrm{I} 88 \mathrm{os}$, Onward ran a regular science series. Subsequently "Our Club" appeared, a column in which four boys debated and discussed temperance topics of the day. The series notes that the boys are "very fond of thrashing out in their own way arguments both for and against many of the things they find existing around them. We are privileged to listen to some of their talks and to follow in their arguments." 53 By this time under the editorship of W. C. Wilson, the magazine continued to feature practical and self-referential items, for example, by giving advice on starting a periodicals subscription club and encouraging members to collect as much money as possible for the regional union's new headquarters. It had clearly achieved influence and a national presence; together with its sister periodical, the Onward Reciter, it claimed a regular circulation of 500,000 copies by $\mathrm{I} 895.5^{54}$

Over the years, the Band of Hope Review had begun to move closer to Onward in style and content-perhaps in acknowledgement of the success of its northern rival or in belated response to changes in the juvenile periodical field. The Review introduced the printing of songs in the I 870 s although it did not publish them as frequently as Onward, and in I880 it published a feature entitled "The Trial of Alcohol," which included entertaining dialogues and recitations suitable for performance. ${ }^{55}$ The assertive tone of the I 892 poem "King Alcohol Must Go!" echoed the lively style of verse in Onward. By the I 890 os, the Review broadened its range to include more heroic and scientific content, thus copying Onward and magazines in the wider children's publishing market. ${ }^{6}$ And by I894, the Review personalised its content by including small photographic portraits of its contributors. In earlier years, it had rarely given writers' names, unlike Onward, which had included authorial signature from the outset. Perhaps in response to the changing landscape of the children's press, the first issues of the Review in I900 included a new feature, the "Editor's Corner," which was similar to the editorial column pioneered by Onward (but without the colloquial title word "chat"). It began to feature jokes and livelier competitions and to take a friendlier, less religious tone. More dramatically, after 1900 it also adopted a new size, shrinking to the same dimensions as Onward. Ultimately, it was difficult to distinguish between the two titles in 
terms of format or content. It is important to note that Onward also began to borrow from the Band of Hope Review. Figure 8 shows an illuminated biblical motto, an item which had been a signature feature of the Review for nearly fifty years before it was adapted by Onward. Both publications also used common blocks, such as the figure of a newsboy which appeared in the Review in June I899 and then in Onward in January I900 and October 1903 .

A comparison of Onward and the Band of Hope Review thus demonstrates that no periodical operated in isolation, especially in niche markets, where editors needed to be aware of their competitors' offerings. They could choose to respond to this competition by maintaining their distinctiveness or, if necessary, by adapting strategies from other periodicals. Onward probably had an advantage from the outset as it was able to position itself against the market leader, the Band of Hope Review, and define itself in oppositional terms, emphasising approachability rather than piety. It showed a consciousness of its Christian mission but also an awareness of the needs of its young readers. In a competitive market that included non-temperance publications, the editors realised the importance of engagement with juvenile consumers in increasingly innovative ways. In the longer term, this proved to be an approach so effective that it was eventually adopted by the Review.

At times, Onward seemed to overstate its own national importance, and its liveliness occasionally became something more like brashness. An I 882 article, for example, exclaims, "Get to the front, boys! We are living in wonderful times, so keep your eyes open. Get early to school, and when you are there make good use of your time. Don't be satisfied with knowing a little, be determined to master whatever you take in hand. Clever boys get to the front. The world's greatest men were clever boys, remarkable for their industry, courage, and perseverance." ${ }_{57}$ While perhaps off-putting to a modern audience, this sense of energetic determination was characteristic of the magazine and perhaps the period as a whole.

Both Onward and the Band of Hope Review had a captive audience, to some extent, through the subscription system mentioned above. The existence of two viable and popular temperance magazines presented a real choice for juvenile consumers, who were capable of swiftly shifting their allegiances in response to the perceived inadequacies or superiorities of either periodical. In the early years, membership figures for the Band of Hope certainly would not have been as large as the circulation numbers for the two magazines, which were widely sold by sympathetic printers and stationers; their audiences thus constituted a much broader imagined community. Details of Band of Hope events and meetings mentioned in the periodicals would have acted as persuasive publicity for non-members who might then be tempted to join. Particularly in Onward, the frequent publi- 
- 20ำ H马 든굴 2y 1 y.

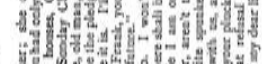
崫

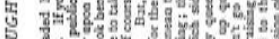
象

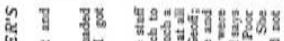
息 -4 . 단

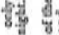

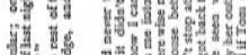
14y

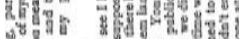

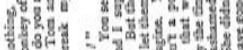
o fins
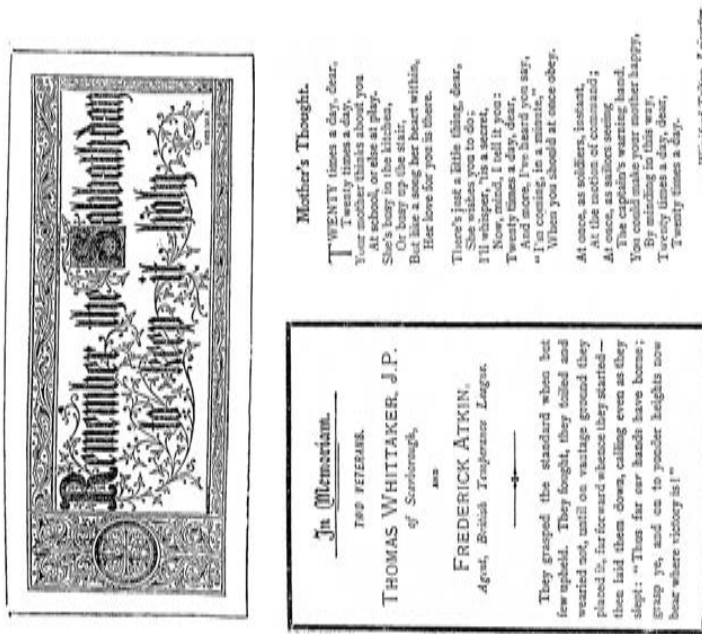

36 theng g a

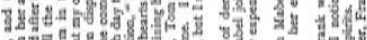

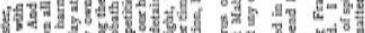
Sif T. 4

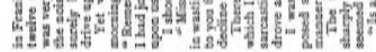

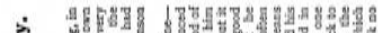

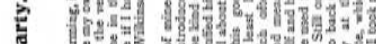
-

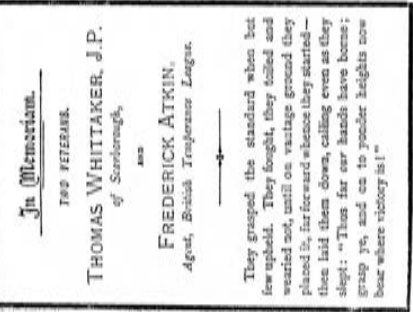


cation of ever-increasing Band of Hope membership figures, along with the publication of features designed to promote interaction between readers and writers, functioned to establish and maintain a friendly sense of community.

The Band of Hope Review ultimately became the beneficiary of Onward's pioneering and innovative spirit. Onward ceased publication as a children's title in I9Iо, becoming the Workers Onward (I9I0-6os), which was intended for the use of Band of Hope workers ("conductors") and was thus only indirectly addressed to children. Study of committee minutes suggests that the widespread distribution of free copies of the magazine in an attempt to preserve market position led to financial problems after I900. It is also possible that Onward suffered in the face of increased competition from the wider range of children's magazines. The Band of Hope Review finally overcame its junior challenger before ultimately ceasing publication in 1937 , when the temperance movement was falling into decline. After the demise of Onward, the Lancashire and Cheshire Band of Hope Union maintained its publishing operations, concentrating its efforts on songbooks, hymnbooks, the Onward Reciter, and an Onward series of prize books. The legacy of the Onward empire took physical form in the construction of Onward House, a meeting and office space funded in part by readers' contributions which still stands today on Deansgate, Manchester.

Onward is a fascinating case study for exploring how magazines negotiated the religious aspects of the temperance message while still providing other, more immediately attractive, elements for young readers. Onward can also be interpreted as a publication with a strong regional identity which achieved national success; as an innovative magazine which promoted a warm relationship with its readers; and as a title that responded to market imperatives, learning from its competitors. It can also be seen as an initially small periodical with limited funding which used lively content to develop a robust readership. Other journals from regional Band of Hope unions, such as the Temperance Lighthouse from Yorkshire, achieved small local circulations briefly in the mid-nineteenth century and then withered. Onward both survived and prospered in a competitive marketplace by employing creative strategies and engaging readers in a common purpose.

University of Central Lancashire

\section{NOTES}

I. Hoyle "Onward!," 3.

2. Harrison, "World of Which We Had No Conception," and Niessen, "Temperance," are standard works.

3. Rowntree and Sherwell, Temperance Problem, 5. This figure includes adults' and children's societies. 
4. Harrison, Drink and the Victorians. See also Longmate, Water-Drinkers, and McAllister, "Rational Recreation."

5. Nicholls, Politics of Alcohol, I03.

6. Berridge, Demons, 36-54.

7. For example, in Liverpool in $1893,2,378$ children were arrested as "dead drunk," I I 3 of whom were under ten. “2,378 'Black Spots on the Mersey,'” $3 \mathrm{I}$.

8. By the I860s, very few juvenile temperance societies existed which had not changed their name to incorporate "Band of Hope."

9. See McAllister, "Rational Recreation."

Io. Shiman, "Band of Hope Movement," 66.

I I. Barker, "Band of Hope Movement," I4.

I2. Harrison, "Press and Pressure Group in Modern Britain," 282.

I3. Anderson, Imagined Communities, 5-7.

I4. Harrison, "World of Which We Had No Conception," I 29.

I 5. McAllister, "Lives and the Souls of the Children."

I6. Murray, "Band of Hope Review," 37.

I7. Mountjoy, "Thomas Bywater Smithies," 47.

I8. Band of Hope Review, June I85 I. Quoted in Mountjoy, “Thomas Bywater Smithies," 47.

I9. Harrison, Drink and the Victorians, 308.

20. Banham describes Boys of England as "arguably the most popular and successful of boys' magazines." Banham, "Boys of England," 69. Temperance periodicals for adults lagged behind the general adult-market leaders. For example, Reynolds's Weekly Newspaper had an estimated circulation of 350,000 in I872. See McWilliam, "Reynolds."

2I. See McAllister, "Lives and the Souls of the Children," for a detailed study of the Lancashire and Cheshire Band of Hope Union.

22 Antrobus, "To Our Readers," I.

23. Beetham, "Open and Closed," 97-98.

24. Wynne, Sensation Novel, 20.

25. The first editor was W. D. B. Antrobus, who appears to have had no other literary or publishing links.

26. Henry, "Temperance and Religion," 38.

27. Ibid.

28. Antrobus, "Preface," iii.

29. See McAllister, "Temperance Periodicals."

30. Whitehead, "Lancashire and Cheshire Band of Hope Union," 2 I.

3I. Onward, the organ of the Preston and District Band of Hope Union, no. 53 , May I 892. This copy survives in the Harris Library, Preston. The content of the rest of the magazine is generic, with only the four pages of local material bound on as the front and end pages. The phenomenon of localisation is worthy of further study. 
32. Antrobus, "Editor's Chat," April ı 868, I60.

33. Ibid., July I 867, I 6 .

34. Ibid., September 1867,48 .

35. Ibid., July I 867 , I 5 .

36. See Law, "Periodicalism," 552. The Boys' Own Paper, for example, reported a circulation of 600,000 in the I 880 s. Dunae, "New Grub Street," 23.

37. Advertisement, 236.

38. Antrobus, “To Our Readers," I.

39. "Pages for the Young," Onward 3:42.

40. "Pages for the Young," Onward 4:58.

4I. The Band of Hope Review printed only sixteen songs, with or without music, over the forty-nine year period between I87I and I900.

42. McGuire, Music and Victorian Philanthropy. See also McAllister, Demon Drink?, for a discussion of temperance music.

43. This William Hoyle, secretary of the regional Band of Hope Union and noted melodist about whom little else seems to be known, should not be confused with the other Mancunian temperance writer, William Hoyle (1832-86).

44. Murray, "The Band of Hope Review," 37.

45. "Cousin Edward's Letter," 44.

46. Barker, Comics, 65. Barker's appreciation of the multifarious nature of the periodical has been a great help in my reading of Victorian periodicals, and I am grateful to the anonymous reviewer who suggested it.

47. Beetham, "Open and Closed"; James, "Trouble with Betsy."

48. Conboy, Press and Popular Culture, 96.

49. Hoyle, "Band of Hope Management," 87.

50. "Pebbles and Pearls," 96.

5I. See also the vignette illustration accompanying Bertha Davies's story, which similarly exemplifies the well-designed page by uniting elements in an attractive whole without using an overt grid system (see figure 5 above).

52. Murray, "Band of Hope Review," 37.

53. Edwards, "Our Club," I 2.

54. Circulation figures are from United Kingdom Band of Hope Union, Annual Report, 48. The Onward Reciter was a compendium of recitation material only, rather than a typical magazine including other elements.

55. "The Trial of Alcohol," 202.

56. "King Alcohol Must Go!," 7.

57. "Get to the Front, Boys!," I 35. 


\section{BIBLIOGRAPHY}

“2,378 'Black Spots on the Mersey.”' Onward 333 (February I 894): 3 I.

Advertisement, Band of Hope Review 59 (November I 865): 236.

Anderson, Benedict. Imagined Communities: Reflections on the Origin and

Spread of Nationalism. London: Verso, I99I.

Antrobus, W. D. B. "Editor's Chat." Onward 25 (July I 867): I 5-I6; 27 (September I 867): 47-48; 34 (April I 868): I $58-60$.

. "To Our Readers." Onward I (July I 865): I-2.

"Preface." In Onward, Volume I, iii. Manchester and London: Lancashire and Cheshire Band of Hope Union and William Tweedie, I865-66.

Banham, Christopher. "Boys of England." In The Dictionary of Nineteenth-Century Journalism, edited by Laurel Brake and Marysa Demoor, 69. London and Ghent: British Library and Academia Press, 2009.

Barker, Martin. Comics: Ideology, Power and the Critics. Manchester: Manchester University Press, 1989.

Barker, W. "The Band of Hope Movement." Onward I 88 (January I 882): I 4.

Beetham, Margaret. "'Open and Closed': The Periodical as a Publishing Genre." Victorian Periodicals Review 22, no. 3 (1989): 96-100.

Berridge, Virginia. Demons: Our Changing Attitudes to Alcohol, Tobacco, and Drugs. Oxford: Oxford University Press, 2013.

Conboy, Martin. The Press and Popular Culture. London: Sage, 2002.

"Cousin Edward's Letter." Onward 27 (September I 867): 44.

Dunae, Patrick A. "New Grub Street for Boys." In Imperialism and Juvenile Literature, edited by Jeffrey Richards, I 2-33. Manchester: Manchester University Press, 1989.

Edwards, Walter E. "Our Club." Onward 428 (January I902): I2-I3.

"Get to the Front, Boys!" Onward I96 (September, I882): I35.

Harrison, Brian. Drink and the Victorians: The Temperance Question in England, I $815-1872.2^{\text {nd }}$ ed. Keele: Keele University Press, I994.

- "Press and Pressure Group in Modern Britain." In The Victorian Periodical Press: Samplings and Soundings, edited by Joanne Shattock and Michael Wolff, 26I-95. Leicester: Leicester University Press, I 982.

—. "“A World of Which We Had No Conception': Liberalism and the English Temperance Press: I 830-I 872." Victorian Studies I3, no. 2 (I969): I $25-58$.

Henry, James. "Temperance and Religion." Onward 27 (I 867): 38-39.

Hoyle, William. "Band of Hope Management: Hints to Speakers." Onward 30 (December I 867): 87.

- "Onward!" Onward I (July I 865): 3 .

James, Louis. "The Trouble with Betsy: Periodicals and the Common Reader in Mid-Nineteenth-Century England." In The Victorian Periodical Press: Samplings and Soundings, edited by Joanne Shattock and Michael Wolff, 349-66. Leicester: Leicester University Press, I982. 
"King Alcohol Must Go!" Band of Hope Review 373 (January I 892): 7.

Law, Graham. "Periodicalism." In The Victorian World, edited by Martin Hewitt, 537-54. London: Routledge, 2012.

Longmate, Norman. The Water-Drinkers: A History of Temperance. London:

Hamish Hamilton, I968.

McAllister, Annemarie. Demon Drink? Temperance and the Working Class.

E-book, Amazon Digital Services, 2014.

-. "The Lives and the Souls of the Children: The Band of Hope in the North

West." Manchester Region History Review 22 (20I I): I-I8.

- "Rational Recreation and Leisure for Children: The Band of Hope in the Twentieth Century." In Recording Leisure Lives: Everyday Leisure in $20^{\text {th }}$ Century Britain, edited by Robert Snape, Helen Puissard, and Matthew Constantine, II3-29. Brighton: LSA Publications, 20 I 2.

—. "Temperance Periodicals." In The Ashgate Research Companion to Nineteenth-Century Periodicals, edited by Alexis Easley, Andrew King, and John Morton. Aldershot: Ashgate, 2015 (forthcoming).

McGuire, Charles E. Music and Victorian Philanthropy: The Tonic Sol-Fa Movement. Cambridge: Cambridge University Press, 2009.

McWilliam, Rohan. "Reynolds, George William MacArthur." In The Dictionary of Nineteenth-Century Journalism, edited by Laurel Brake and Marysa Demoor, 539. London and Ghent: British Library and Academia Press, 2009.

Mountjoy, Peter Roger. "Thomas Bywater Smithies, Editor of the British Workman." Victorian Periodicals Review I 8, no. 2 (I985): 46-56.

Murray, Frank. "The Band of Hope Review." In The Dictionary of NineteenthCentury Journalism, edited by Laurel Brake and Marysa Demoor, 37. London and Ghent: British Library and Academia Press, 2009.

Nicholls, James. The Politics of Alcohol: A History of the Drink Question in England. Manchester: Manchester University Press, 2009.

Niessen, Olwen. "Temperance." In Victorian Periodicals and Victorian Society, edited by J. Don Vann and Rosemary VanArsdel, 25 I-77. Toronto: University of Toronto Press, I994.

"Pages for the Young." Onward 3 (September I 865): 42-43.

"Pages for the Young." Onward 4 (October I 865): 56-60.

"Pebbles and Pearls." Onward I93 (June I 882): 96.

Rowntree, Joseph, and Arthur Sherwell. The Temperance Problem and Social Reform. $8^{\text {th }}$ ed. London: Hodder and Stoughton, I900.

Shiman, Lilian Lewis. "The Band of Hope Movement: Respectable Recreation for Working-Class Children.” Victorian Studies I 7, no. I (I973): 49-74.

“The Trial of Alcohol." Band of Hope Review 23 I (March I 880): 202.

United Kingdom Band of Hope Union. Annual Report. London: United Kingdom Band of Hope Union, I 895.

Whitehead, George. "The Lancashire and Cheshire Band of Hope Union."

Onward I4 (I866): 2 I.

Wynne, Deborah. The Sensation Novel and the Victorian Family Magazine. Basingstoke: Palgrave Macmillan, 200I. 